poles apart from the ordered routine of the landsman, who can have no inkling of its distance from his way of life; but, rough and uncomfortable as the life of a fisherman may be, the ceaseless struggle against the unending hostility of the elements and the ever-changing beauty, probably seldom consciously appreciated, of their infinite variety bring a primitive satisfaction that drives men to sea again and again in spito of all sea-born vows to swallow the anchor for good.

The last two ehapters discuss the possibility of farming the sea, and the future of fisheries and man. The artificial cultivation of fresh-water fishes has a long history and a bright future, but no more than the first tentative experimonts have yet been made in cultivating marine fishes - the artificial rearing of fry, the transplantation of young fish to rich feeding grounds, and the fertilization of semi-enclosed areas of the sea. One wonders whether pouring the untreated sewage of much of northern Europe into the North Sea can have had any offect in making it one of the finest fishing grounds of the world, or whether the suggested ploughing of the bottom to stimulate the production of the benthos which forms the diet of so many food fishes could increase the harvest. The human population explosion results in an ever-increasing demand for food protein; Dr. Ommanney speculates about the possibilities of satisfying the demand with the products of the sea, and on the effects of the radioactive wastes that we dump into the depths in 'leak proof' containers when inovitably they do leak. "There seems to be no limit to what man may achieve with his technology and his formidable know-how. . . Nevertheless, the abuse of his own know-how threatons his very existonce and already casts a lengthoning shadow which reaches even to the uttermost depths of the sea."

Dr. Ommanney's book will be enjoyed equally by the professional biologist and by the layman for whom it is primarily intended. It is well illustrated with colourod and monochrome photographic plates and with numerous line drawings of excellent quality. There are, however, several howlers that a more eareful final revision might have avoided; the Woberian ossicles have certainly not bocome the hearing bones of the oar of higher animals (p. 45), the claspers of elasmobranchs are not, as Agassiz mistakenly supposed, "pressed together so that their grooved innor faces form a tube along which the sperm flows" but are insertod singly into the female passage (p. 73); no carefully measured Basking shark has reached "a length of 40 feet", $30 \mathrm{ft}$. is nearer the mark (p. 79); the marine lancelet Branchiostoma is not the same creature as the "sand launce", which is the sand eel Ammodytes (p. 197), and Fig. 19 purporting to show gill rakers is a failure. These regrettable lapses form the few shadows that contrast with the brilliance of the rest of the book.

L. HaRrison MatTHEws

\section{PURPOSE AND MEANING OF A UNIVERSITY}

The Modern University

By Prof. G. L. Brook. Pp. 192, (London: André Deutsch, 1965.) 25s. not.

DROF. G. L. BROOK, Smith professor of English language and medieval English literature in the University of Manchester and a Pro-Vice-Chancellor, has writton an ascount of univorsity problems to-day similar to that of 'Bruce Truscott' some twenty years ago. There is the same easo of expression but more authority as well as balance about the whole book. It is a little disappointing, therefore, that the production of such an admirable book should fall considerably short of what was possible in the midst of the War at a third of the price.

Prof. Brook's opening chapter gives a brief discussion of the purpose of a university, and this, together with the following chapter on entrance requirements, and an appendix on the organization of a modern university, should make plain to prospective students, and thoir parents, much that sometimes porplexes thom. In the suceeeding chapters he writes on students and on lectures and tutorials with a refreshing sanity and humour, as well as with balance; his remarks could be disconcerting to the extremist. In general, however, the most valuable chapters in the book are those which deal with books, with professors and lecturers and with acadomic freedom. The first will be wolcomed by those urging more generous provision for university libraries. Librarians should be encouraged by the clear understanding shown of their difficulties and also of the problem of book-buying by students. Tho second corrects a misleading impression conveyod by 'Bruce Truscott' and should assist in giving a cloarer understanding outside the university of the problems involved in the relations betweon research and teaching. Together with the final chapter on expansion, it brings down to earth some of the wilder statements and arguments of those who soek to determine university expansion by service to political doctrine rather than by reference to public needs and the real nature or purpose of $a_{1}$ university.

For the chapter on academic freedorn alone The Modern University would be welcome. Prof. Brook's exposition of the issues, including those aspects arising from the relations of university teachers with one another and the amount of freedom that students should enjoy, could scarcely be improved. He sees the danger at prosent as so real that our universitios will do well to keep the very considerable freodom they have, and he bolieves that the chief threat comes from well-disposcd persons, genuinely interested in education but who value other things more highly. The threat from outside is largely the result of the success of universities, and Prof. Brook shows clearly how the oar-marked grant can act in this way. The greatest single external threat to academic freedom to-day is the dependence on the State for so large a proportion of the university's income. The greatest internal threat is indifference among university teachers, or the practice of 'taking it for granted'; here he includes the fact that the scholar is reluctant to take his or her share in administration. Nor does he beliove that the University Grants Committeo will by itself suffice. For the defence of academic freedom it is necessary to convince public opinion that the State ought not to exercise the power it possesses. He adds that accordingly maintenance of a high standard of administrative efficiency under acadomic control is a most important safeguard of academic freedom, that many important decisions in university affairs should not rest entirely in the hands of one man, and that students, as well as teachers, have rights to be safeguarded.

Prof. Brook closes this chapter on a note of responsibility addressed particularly to the university toacher. That is the keynote of his final chapter, which includes many frank but uncomfortable words for student as well as teacher and administrator. Ho brings a timoly pragmatic point of view to bear on the whole problem of expansion, arguing that the important qucstion is whether potential students can profit by a university education sufficient to justify the considorable expenditure of time and money involvod. He reminds us of the limits set to expansion by the availability of university teachers of the right calibre, and that the number of students who could profit from some other form of highor education is very much larger than the numbor of those whose propor place is in a university. Ho has constructive suggostions for breaking down existing barriers between school and university teaching. The whole tone of the book is a complete answer to those who accuse the university of being conservative, out of date and unwilling to face modern opportunities. Prof. Brook is to be congratulated on a most readable and timely book. R. BRIGHTMAN 